\title{
Sustainable Leisure Landscapes in Icelandic Rural Communities: A Multidisciplinary Approach
}

\author{
Rannveig Ólafsdóttir ${ }^{1}$, Anna Dóra Sæbórsdóttir ${ }^{1}$, Jorrit Noordhuizen ${ }^{2} \&$ Wieteke Nijkrake ${ }^{2}$ \\ ${ }^{1}$ Institute of Life and Environmental Sciences, University of Iceland, Iceland \\ ${ }^{2}$ NOHNIK Architecture and Landscapes, The Netherlands \\ Correspondence: Rannveig Ólafsdóttir, Department of Geography and Tourism Studies, Institute of Life and \\ Environmental Sciences, University of Iceland, IS-101 Reykjavík, Iceland.
}

$\begin{aligned} & \text { Received: October 30, } 2018 \quad \text { Accepted: November 23, } 2018 \quad \text { Online Published: November 25, } 2018 \\ & \text { doi:10.5539/jms.v8n4p54 }\end{aligned}$ URL: https://doi.org/10.5539/jms.v8n4p54

\begin{abstract}
The rapid increase of tourism in the Arctic highlights the critical importance of holistic planning of land use for tourism to ensure that recreational activities are only developed where natural and cultural environment is able to sustain their impact. This paper aims to devise a holistic plan for use of land for Icelandic tourism based on landscape analysis and stakeholders' perceptions, and to critically discuss the role of holistic approaches and zoning principles in such planning with regard to different market groups of visitors. A case study was conducted in Skaftárhreppur municipality in southern Iceland. Geographical information systems (GIS) were used to analyse its suitability for the various forms of recreational activity based on stakeholders' perceptions, landscape sensitivity, the area's recreational opportunity spectrum (ROS), and visitor type according to the purism scale model. The results reveal a lack of balance between the area's current recreational use and its landscape sensitivity, something which reflects many of the negative aspects of the exponential growth within Icelandic tourism which has taken place over the past decade. The results further stress the importance of appropriate infrastructure to channel the increasing flow of mass tourism and to direct this flow to carefully chosen focal points. In seeking to develop site-specific zoning for the different market groups, focal points have proven to be a critical management tool. By controlling the number, type and location of visitors, their flow is regulated, and thereby the impact of tourism is managed. The use of well-defined focal points in the zoning procedures will reduce the environmental and social pressure from tourism, reduce the cost of maintaining infrastructure incurred by communities, ensure visitor satisfaction, and protect the most sensitive areas from overexploitation by tourism.
\end{abstract}

Keywords: tourism, land use planning, zoning, ROS, leisure landscapes, sustainability, Iceland

\section{Introduction}

It is well known that a flourishing tourism industry can have a range of positive impacts on a society and thereby benefit the economic development of its communities. As such, tourism is usually regarded as a positive counteraction in many Arctic rural communities experiencing the migration of their inhabitants to more densely-populated areas. Likewise, it is well known that, if not properly managed, tourism can also have considerable negative impacts, such as overtourism, pollution, littering and trampling, bringing about the deterioration of natural and cultural resources and ultimately of the tourist destination itself.

The exponential increase of tourism in the Arctic in recent decades has drawn the attention of numerous researchers (e.g., Zelenskaya, 2018; Keskitalo, 2017; de la Barre, Maher, Dawson, Hillmer-Pegram, Huijbens, Lamers, Liggett, Müller, Pashkevich, \& Stewart, 2016; Huijbens, 2015; Huijbens \& Alessio, 2015; Müller, 2015; Kaján, 2014; Müller \& Brouder, 2014; Lemelin, Maher, \& Ligget, 2013; Fay \& Karlsdóttir, 2011; Grenier \& Müller, 2011; Hall \& Saarinen, 2010), highlighting the critical importance of a holistic understanding of the impacts of tourism on Arctic environments and communities. In Iceland tourism has grown rapidly in the past decade, with an escalating annual increase as high as 40\% from 2015 to 2016 (ITB, 2017). Iceland's dynamic landscapes and diverse natural scenery have long been the Icelandic tourism industry's primary resource. The tourism industry's response to the escalating growth of tourism has in particular been to increasingly expand tourism infrastructure and services. Furthermore, in the past few years there has been a vast increase in recreational outdoor activities such as hiking, horse riding, mountain biking and trail running as well as the use 
of snowmobiles, 4WD vehicles and ATV, all of which are likely to increase tourism impact on Icelandic nature and thereby on visitors' experience. It has been stressed (e.g., Senes \& Toccolini, 1998; de la Barre, et al., 2016) that recreational activities should only be developed when the natural and cultural environment is capable of absorbing the impact of their development. In order to do so, and in order to preserve and sustain what made the tourist destination attractive in the first place, well-defined spatial land use planning and tourism management are critical. Moreover, sustainable land-use planning for tourism must be grounded in a holistic standpoint by integrating scientific and local knowledge (e.g., Ólafsdóttir \& Júlíusson, 2000) in terms of stakeholders' views, the wishes and experiences of visitors, and the suitability of the land for various forms of recreation. This is of particular importance in Arctic environments given that, as has been demonstrated by e.g., Müller (2015) Arctic tourism is not characterized by one particular form, and must therefore be viewed in the context of its setting. Thus, it is fundamental to develop an acceptable land use plan for tourism in rural Arctic communities which integrates a range of approaches to knowledge, and to integrate both top-down and bottom-up approaches. In order for local stakeholders to have a buy-in and a degree of empowerment in the process of tourism development, the inclusion of a range of stakeholders is furthermore fundamental to the sustainability of the process (e.g., Ólafsdóttir \& Dowling, 2014). Accordingly, each stakeholder group makes a contribution towards changing the nature of the area's tourism, and as such each group's success is dependent upon the contribution of others.

This paper focuses on sustainable leisure landscapes in Icelandic rural communities, attempting to preserve and stimulate their ecological quality, economic prosperity, social wellbeing and cultural history. Its general aim is to devise a holistic land use plan for tourism based on landscape analysis and stakeholders' perceptions, and to critically discuss the role of a holistic approach and zoning principles in such planning. This paper forms part of a larger study focusing on tourism spatial planning and design potentials in Skaftárhreppur municipality in southern Iceland ( $c f$. Noordhuizen, Nijkrake, Ólafsdóttir, \& Sæpórsdóttir, 2016).

Skaftárhreppur municipality was selected as a pilot case for this study (Figure 1). It is a traditional sheep farming community for which the importance of tourism has grown extensively in the past two decades. Skaftárhreppur is the second largest municipality in Iceland, covering some $6945 \mathrm{~km}^{2}$ (NLSI, 2018), stretching from the coast in the south to the country's uninhabited interior highlands in the north. The population of Skaftárhreppur was 475 inhabitants on $1^{\text {st }}$ of January 2017, of which 140 live in the municipality's only town, Kirkjubæjarklaustur (Statistics Iceland, 2017). The population has suffered from gradual depopulation for a number of decades, but in the past few years this process has halted and the population has slowly begun to increase (Statistics Iceland, 2017), most likely due to the increasing role of tourism in the area (e.g., Sæpórsdóttir \& Stefánsson, 2017) as a major mechanism in arresting the decline of agricultural employment and thereby as a mechanism for agricultural diversification. A section of the municipality's highlands now forms part of Vatnajökull National Park (VNP), which was established in 2008 (Icelandic act no. 60/2007). VNP covers an area of nearly 14,000 $\mathrm{km}^{2}$, or $14 \%$ of Iceland (VNP, 2017). The park is divided into four administrative territories, of which the western territory is located in Skaftárhreppur municipality. Since 2010 Skaftárhreppur municipality, together with two adjoining municipalities, furthermore form a joint geopark, Katla geopark. In 2011 Katla geopark was accepted into the European Geoparks Network and jointly into the UNESCO Global Geopark Network (e.g., Ólafsdóttir \& Dowling, 2013; UNESCO Global Geoparks, 2017).

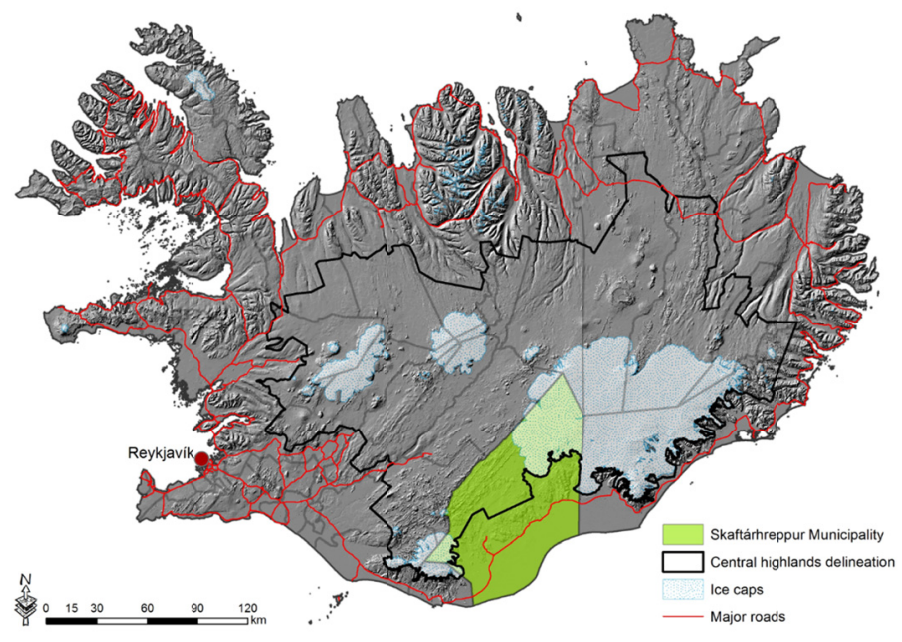

Figure 1. Location of Skaftárhreppur municipality in Iceland 
Skaftárhreppur lies within the neo-volcanic zone that runs through Iceland from SW to NE. As such all of its geological formations are young. Its bedrock is mainly made up of interglacial lava flows, while most of its mountains have been formed by subglacial eruptions (Jóhannesson, 2014). A large part of the municipality's natural environment is characterised by a vast basaltic lava field which originated from the Laki eruption of 1783-1784 which ranks as the world's second largest basaltic flood lava eruption in recorded history (Thordarson, Larsen, Steinpórsson, \& Self, 2003). Skaftárhreppur's natural vegetation is largely characterised by unique and fragile moss cover (Guðjónsson \& Gíslason, 1998). The municipality's unique and spectacular nature is by far the number one factor attracting tourists to the area (Sæpórsdóttir, Ólafsdóttir, \& Ólafsson, 2009). Aside from its diverse and distinctive nature, the major strengths of the municipality as a tourist destination are its relatively short distance from the capital area and the country's largest international airport, that Iceland's Route 1 (a.k.a. Ring Road) crosses the municipality, the presence of Vatnajökull national park and Katla Geopark within its borders, extensive wilderness areas, combined with its rich culture and history. Its major weaknesses are its very small population, monotonous economy, limited infrastructure, lack of professionally-qualified tourism staff, lack of recreational activities, and lack of tourism planning and management (Visit South Iceland \& ITB, 2018). The majority of the area's tourists drive through the municipality on Iceland's Route 1 ( $c f$. Figure 1), stopping at the most scenic spots along the way, most of which are connected with the vast lava field. A small proportion of tourists however visit the Laki eruption crater rows located some $40 \mathrm{~km}$ into the highlands from Route 1 . In 2017 this group of tourists totalled 8800 (bórhallsdóttir \& Ólafsson, 2018). A popular mountain road also runs from Route 1 to Landmannalaugar, which is the most popular highland destination in Iceland (ITB, 2016).

\section{Methods}

In devising a holistic land use plan for tourism in Skaftárhreppur municipality a multi-disciplinary approach was adopted. In order to better understand what makes Skaftárhreppur municipality a competitive tourist destination and benefits its local population, as well as to identify the potential impacts of leisure activities on its landscape and of various tourism activities on the area's recreational settings, a participatory action research (PAR) approach was taken. A focus group was formed, comprising ten people including local stakeholders and expertise, with Skaftárhreppur's mayor the planning representative, the chair of the local environmental and nature conservation board, the director of Visit Klaustur, the manager of Vatnajökull National Park and the director of Katla Geopark representing local stakeholders, and tourism and spatial planning researchers as well as landscape architecture, architecture and design researchers representing the expertise. The purpose of the focus group interaction was to obtain insights and produce data that would not be available were it not for the dialogue which took place within the group. Focus groups have proven to be especially useful where only limited knowledge exists on a given subject (Stewart \& Shandasani, 1990). The researchers' role within the focus group was to ask critical questions, which is in line with participatory action research that attempts to change a social system by stimulating critical thinking and discussion while at the same time generating knowledge about it, as well as to address political and technical issues by creating new knowledge through the solving of practical problems (e.g., McDonald, 2012).

Three comprehensive group discussion meetings were held, the first in October 2015, the second in January 2016 and the last in April 2016. The first group meeting focussed on discussions of the identification of the strengths and weaknesses of the area as a tourist destination and the optimal relationship between locals and tourists. The research experts had prepared a list of open-ended questions aimed at providing information on sustainable tourism and leisure landscapes and directing the discussions. Based on the results from the first group discussions and available geographical data on environmental settings and ecological sensitivity, optional landscape entities representing spatial characteristics of the area were evaluated using geographical information systems (GIS). A landscape entity map was then obtained from spatial analysis of the area's topography, geology, vegetation, soils, ecological sensitivity and land use. The second group meeting focused on discussions of these landscape entities, impacts of the various tourism recreational activities and potential recreational settings within the municipality. The third group meeting had as its focus joint discussions of a proposed land use plan for sustainable tourism development within the municipality.

GIS was further used to analyse the suitability of the area for the various forms of recreation based on the results from the focus group meetings and the different landscape entities, as well as a map representing the area's recreational opportunity spectrum (ROS) and existing data on tourists' perceptions categorised according to the purism scale model (e.g., Hendee, Catton, Marion \& Brockman, 1968; Stankey, 1973, Ólafsdóttir, Sæpórsdóttir \& Runnström, 2016) obtained from three popular tourist sites within the municipality's highlands area ( $c f$. Sæpórsdóttir, 2010). In the purist scale model visitors are divided into groups according to their preferences regarding the natural qualities at the various locations. At one end of this scale are purists who seek solitude and 
simple facilities in an unspoiled environment, while at the other are urbanists who are not sensitive to the number of travellers at the location, do not respond negatively to environmental damage and appreciate good services and facilities. The ROS map was based on four classes obtained from Newsome, Moore \& Dowling, et al. (2013), namely i) primitive, ii) semi-primitive, iii) roaded natural, and iv) developed (Table 1). Due to the significant functional difference between the highland and lowland areas as regards tourism experiences and expectations, the roaded natural class was further subdivided into roaded natural lowland and roaded natural highland. These five classes were then analysed according to physical, social and managerial management factors according to Newsome et al. (2013) and adjusted on the basis of the stakeholders' perceptions. Suitable recreational zones were then determined based on the different landscape entities classified, the ROS classification, as well as tourists' perceptions according to the purism scale model.

Table 1. ROS indicators for planning sustainable leisure landscapes in Icelandic rural communities, adapted from Newsome et al. (2013)

\begin{tabular}{|c|c|c|c|c|c|c|c|}
\hline CLASS & \multicolumn{7}{|l|}{ CRITERIA } \\
\hline \multirow{2}{*}{$\begin{array}{l}\text { Management } \\
\text { factors }\end{array}$} & \multicolumn{3}{|l|}{ Physical } & \multicolumn{2}{|l|}{ Social } & \multicolumn{2}{|l|}{ Managerial } \\
\hline & Accessibility & Naturalness & Size & $\begin{array}{l}\text { Social } \\
\text { interaction }\end{array}$ & $\begin{array}{l}\text { Acceptability } \\
\text { of tourism } \\
\text { impact }\end{array}$ & $\begin{array}{l}\text { Level of site } \\
\text { development }\end{array}$ & Regulation \\
\hline Developed & $\begin{array}{l}\text { Areas } \leq 5 \mathrm{~km} \\
\text { from highway } \\
\text { no } 1 \text { and larger } \\
\text { settlement (i.e. } \\
\text { Klaustur) }\end{array}$ & $\begin{array}{l}\text { No distance } \\
\text { criteria on } \\
\text { power lines and } \\
\text { telecommunicat } \\
\text { ion } \\
\text { constructions }\end{array}$ & $\begin{array}{l}\text { No size } \\
\text { criteria }\end{array}$ & $\begin{array}{l}\text { Very high } \\
\text { along roads } \\
\text { and tracks } \\
\text { and } \\
\text { developed } \\
\text { areas }\end{array}$ & $\begin{array}{l}\text { High - } \\
\text { Substantial } \\
\text { impacts } \\
\text { evident and } \\
\text { accepted }\end{array}$ & $\begin{array}{l}\text { High level tourism } \\
\text { infrastructure - } \\
\text { Roads and site } \\
\text { facilities for } \\
\text { intensive use }\end{array}$ & $\begin{array}{l}\text { Control obvious } \\
\text { and numerous } \\
\text { via design, } \\
\text { signs and } \\
\text { staffing }\end{array}$ \\
\hline $\begin{array}{l}\text { Roaded } \\
\text { natural } \\
\text { lowland }\end{array}$ & $\begin{array}{l}\text { Lowland areas } \\
\leq 5 \mathrm{~km} \text { from any } \\
\text { class of road } \\
\text { and settlement }\end{array}$ & $\begin{array}{l}\text { No distance } \\
\text { criteria on } \\
\text { power lines and } \\
\text { telecommunicat } \\
\text { ion } \\
\text { constructions }\end{array}$ & $\begin{array}{l}\text { No size } \\
\text { criteria }\end{array}$ & $\begin{array}{l}\text { High along } \\
\text { roads and } \\
\text { tracks and } \\
\text { settlements }\end{array}$ & $\begin{array}{l}\text { Moderate } \\
\text { impact } \\
\text { accepted in } \\
\text { specific areas }\end{array}$ & $\begin{array}{l}\text { Moderate level } \\
\text { tourism } \\
\text { infrastructure - } \\
\text { Roads, site } \\
\text { facilities for } \\
\text { moderate use and } \\
\text { comfort }\end{array}$ & $\begin{array}{l}\text { Moderate } \\
\text { control \& } \\
\text { regulation via } \\
\text { site design and } \\
\text { signs }\end{array}$ \\
\hline $\begin{array}{l}\text { Roaded } \\
\text { natural } \\
\text { highland }\end{array}$ & $\begin{array}{l}\text { Highland areas } \\
\leq 5 \mathrm{~km} \text { from any } \\
\text { class of road } \\
\text { and settlement }\end{array}$ & $\begin{array}{l}\text { No distance } \\
\text { criteria on } \\
\text { power lines and } \\
\text { telecommunicat } \\
\text { ion } \\
\text { constructions }\end{array}$ & $\begin{array}{l}\text { No size } \\
\text { criteria }\end{array}$ & $\begin{array}{l}\text { Moderate } \\
\text { along roads } \\
\text { and tracks }\end{array}$ & $\begin{array}{l}\text { Low impact } \\
\text { accepted in } \\
\text { specific areas }\end{array}$ & $\begin{array}{l}\text { Moderate level } \\
\text { tourism } \\
\text { infrastructure - } \\
\text { Roads, site } \\
\text { facilities for } \\
\text { comfort and } \\
\text { security }\end{array}$ & $\begin{array}{l}\text { Low control \& } \\
\text { regulation via } \\
\text { site design and } \\
\text { signs }\end{array}$ \\
\hline Semi-primitive & $\begin{array}{l}\text { Areas } \geq 3 \mathrm{~km} \\
\text { distance from } \\
\text { any class of } \\
\text { road }\end{array}$ & $\begin{array}{l}\text { Areas } \geq 3 \mathrm{~km} \\
\text { distance from } \\
\text { power lines and } \\
\text { telecommunicat } \\
\text { ion } \\
\text { constructions }\end{array}$ & $\begin{array}{l}\text { Areas }> \\
25 \mathrm{~km} 2\end{array}$ & Low & $\begin{array}{l}\text { Minor impacts } \\
\text { accepted }\end{array}$ & $\begin{array}{l}\text { Low - } \\
\text { Natural appearing } \\
\text { setting, structures } \\
\text { rare and isolated }\end{array}$ & $\begin{array}{l}\text { On-site } \\
\text { regulations } \\
\text { subtle, if } \\
\text { present at all }\end{array}$ \\
\hline Primitive & $\begin{array}{l}\text { Areas } \geq 5 \mathrm{~km} \\
\text { distance from } \\
\text { any class of } \\
\text { road }\end{array}$ & $\begin{array}{l}\text { Areas } \geq 5 \mathrm{~km} \\
\text { distance from } \\
\text { power lines, } \\
\text { telecommunicat } \\
\text { ion } \\
\text { constructions }\end{array}$ & $\begin{array}{l}\text { Areas }> \\
100 \mathrm{~km} 2\end{array}$ & Few contacts & Not acceptable & $\begin{array}{l}\text { None - } \\
\text { No site } \\
\text { development, no } \\
\text { structures }\end{array}$ & $\begin{array}{l}\text { No on-site } \\
\text { regulation, } \\
\text { reliant on } \\
\text { self-policing }\end{array}$ \\
\hline
\end{tabular}

Tourism management requires decisions and spatial interventions on multiple scale-levels (e.g., Saarinen, Rogerson \& Hall, 2017). Accordingly, the final design of the plan was based on a multi-scale planning approach. Each scale level represents its own particular importance and value. The small-scale level represents the holistic strategic zoning plan for the whole municipality. The medium-scale level represents the assignment of focus and hierarchy to the recreational attractions or focal points offered to tourists. The large-scale level represents the need for specific and appropriate site design and planning of the potential recreational attractions. 


\section{Results}

\subsection{Current Situation}

The results reveal a lack of balance between the area's current recreational use and landscape sensitivity, reflecting a number of negative exponential growth trends within Icelandic tourism in recent years. Decisions on where to locate new tourism infrastructure are currently being made mainly on the basis of pragmatic considerations rather than in-depth knowledge of the landscape, emphasizing the area's general lack of recreational zoning and a holistic spatial plan for long-term tourism development. A detailed mapping of the current situation as regards the area's tourism services and facilities, recreational activities and transportation network is given in Noordhuizen et al. (2016). This uncontrolled situation, whereby tourists come first and the reaction of locals comes second, reflects a widely-held governmental belief that tourism is a catalyst for rural development, where a single development is typically seen as a springboard for sustaining the viability of the rural area in question and putting it on the map (Gill, 1998). The critical role of tourism in rural development is likewise often seen as a positive counteraction to the migration of rural populations to more densely-populated areas (e.g., Ólafsdóttir \& Runnström, 2009; Ólafsdóttir \& Dowling, 2014; Sæpórsdóttir \& Stefánsson, 2017). If left unregulated, however, tourism growth reinforces the complexity of the situation, which in the long run will tend to increase the area's lack of balance and thereby gradually decrease the economic benefits of tourism. Long-term tourism planning and management is therefore of critical importance. According to Gill (1998) the challenge of rural tourism planning is to strike a balance between the differing needs of tourists and residents and those a changing society and environment. She emphasizes that this balance can only be obtained by involving all stakeholders in the establishment of tourism, especially where tourism is the primary economic activity in the area in question, as is the situation in Skaftárhreppur municipality.

\subsection{Managing the Flow}

The results of this study indicate that in order to sustain rural communities, the key issue is to manage the flow of tourists. The results further stress the importance of appropriate infrastructure to canalize the increasing flow of mass tourism which currently characterises the municipality's most popular destinations. This is vital in order to better manage tourism and bring about a reduction of environmental impact in other recreational areas, and thereby increase visitor satisfaction. This entails strategic choices about where to locate focal points for mass tourism and other marketing groups according to the purism scale model, as well as where to exclude tourism in the landscape (Figure 2). Focal points are a critical management tool, and by controlling their number and location, the flow of tourists can be regulated and tourism impact thereby limited. There is also a need for appropriate site design of attractions both from a functional and aesthetic perspective. The functional perspective addresses the importance of well-designed infrastructure to avoid damage to the landscape as a result of mass tourism, well-designed information signs and facilities such as toilets, litter bins, etc. The aesthetic perspective addresses the importance of site-specific design, i.e., maximizing and supporting the experience of the local landscape and a character which is visually appropriate. It is furthermore important that tourism infrastructure in environmentally sensitive areas is designed and constructed in such a way as to stimulate environmental experiences on the part of tourists and increase their environmental awareness.

As such, the key takeaways from the results of this study as regards planning long-term tourism in environmentally sensitive landscapes such as those found in Iceland are: i) balance, which can only be achieved by involving all stakeholders; ii) zoning, to separate different marketing groups, limit the number of visitors to certain areas and exclude them from the most environmentally sensitive areas; and iii) environmental awareness, which in the long run will have a positive impact on the area's sustainable balance. The framework which will promote these key principles has to be based on a holistic overview in order to increase understanding of the resource and its potential uses (Figure 3). 
A: Numerous un-planned tourist destinations
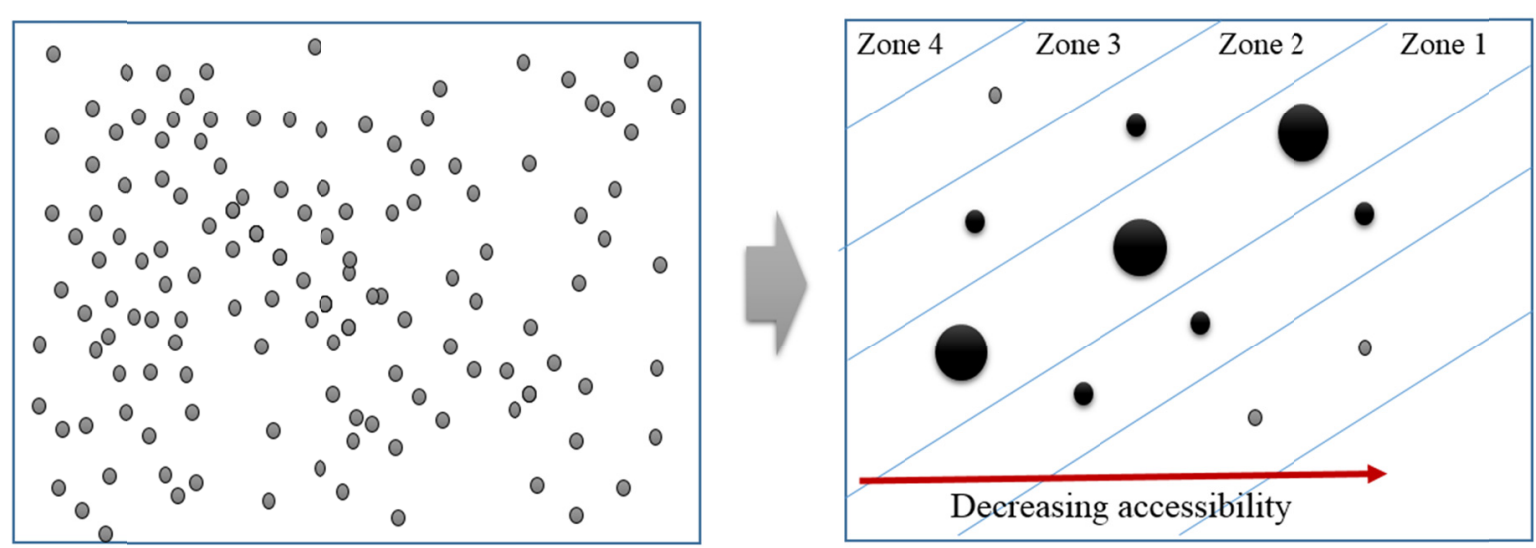

B: Strategically selected focal points adjusted to appropriate zones and desired visitor groups

\section{Focal points}

Infrastructure and service aimed for capturing the flow of mass tourism (urbanists)

- Infrastructure and service aimed for visitor seeking more connection to local environment (neutralists, purists)

- Primitive infrastructure (strong purists, purists)

Figure 2. A conceptual model representing management of tourism flow using strategically selected focal points to limit and control the environmental and social impact of tourism.

Key principle

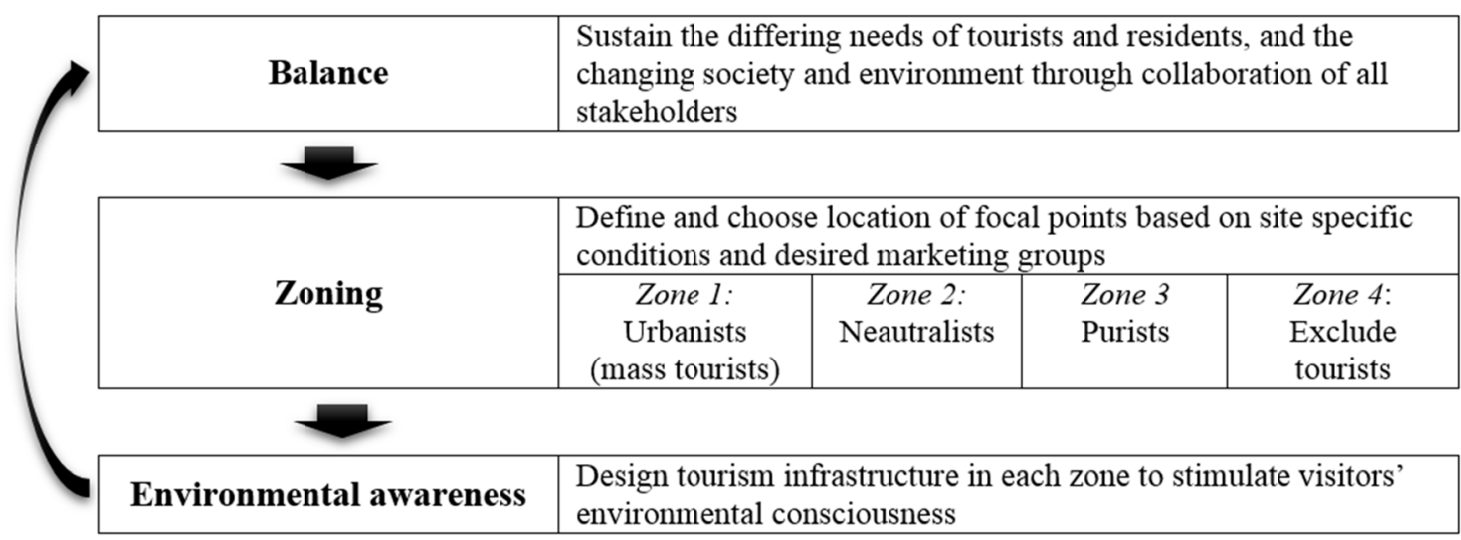

Figure 3. Key principles when planning long-term rural tourism in environmentally sensitive landscapes

The results further stress how important it is that strategic decisions concerning the location of focal points are carefully discussed by all stakeholders and that decisions are based on mutual cooperation between stakeholders in order to avoid future conflicts surrounding land use. In establishing desirable conditions public participation is likewise important, and according to Williams \& Gill (1994) constitutes perhaps the single most important element of growth management. Thus, when seeking to conserve leisure landscapes in Icelandic as well as Arctic rural communities, the results of this study suggest that the following six principles are fundamental in tourism planning: i) Use of a holistic approach to obtain an overview of landscape diversity and to understand the interrelationship between different landscape entities as well as between potential environmental and social impacts; ii) Acknowledgment of the landscape as both ecologically and economically valuable; iii) Planning and design for different marketing groups of visitors on the Purism scale through zoning procedures; iv) Hierarchal 
categorisation of the landscape with regard to the desired marketing groups and creation of specific focal points with varying degrees of infrastructure and services; v) Preservation of rural communities through provision of new infrastructure and services in existing villages; vi) Utilisation of what already exists (Table 2).

Table 2. Six major principles for achieving a sustainable leisure landscapes in Icelandic rural communities ( $c f$. Noordhuizen et al., 2016)

\begin{tabular}{|c|c|c|}
\hline & Principle & Reasoning \\
\hline 1 & $\begin{array}{l}\text { Use a holistic approach to obtain an overview of landscape } \\
\text { diversity and to understand the interrelationship between } \\
\text { different landscape entities, and potential environmental and } \\
\text { social impacts }\end{array}$ & $\begin{array}{l}\text { Avoid exerting pressure on highly-sensitive landscape types. } \\
\text { Value the diversity of the landscape and determine the tourism } \\
\text { carrying capacity of each landscape entity, in order to decide if } \\
\text { and how to utilize it for recreational purposes }\end{array}$ \\
\hline 2 & $\begin{array}{l}\text { Perceive the landscape as both ecologically and economically } \\
\text { valuable }\end{array}$ & $\begin{array}{l}\text { Better preservation of the landscape ensures long-term economic } \\
\text { profit for tourism industries. Do not spoil the landscape with a } \\
\text { sprawl of ad hoc new buildings and infrastructure. }\end{array}$ \\
\hline 3 & $\begin{array}{l}\text { Plan and design for different market groups of visitors through } \\
\text { zoning }\end{array}$ & $\begin{array}{l}\text { Make use of the diversity of the landscape to offer a range of } \\
\text { experiences for different market groups. }\end{array}$ \\
\hline 4 & $\begin{array}{l}\text { Hierarchically categorise the landscape with regard to the } \\
\text { desired market group of visitors at each site, and create } \\
\text { specific focal points with varying degrees of infrastructure and } \\
\text { services }\end{array}$ & $\begin{array}{l}\text { Not every site of natural or cultural heritage is equally important. } \\
\text { Decide which attractions will form focal points for tourism } \\
\text { development, which are of secondary or tertiary value and } \\
\text { which, where applicable, should be preserved and not introduced } \\
\text { to tourists. }\end{array}$ \\
\hline 5 & $\begin{array}{l}\text { Preserve rural communities through provision of new } \\
\text { infrastructure and services in existing villages }\end{array}$ & $\begin{array}{l}\text { Villages function as the heart of the rural community, hosting } \\
\text { the main service centres and facilitating supermarkets, gas } \\
\text { stations, restaurants, hotels, etc. Whenever possible new } \\
\text { facilities should be built within the village so as to preserve the } \\
\text { livelihood of its inhabitants in the long-term. }\end{array}$ \\
\hline 6 & Make use of what already exists & $\begin{array}{l}\text { In tourism planning more attention should be paid to the actual } \\
\text { experience of tourists in each area under current conditions, } \\
\text { rather than on the extension of the road network to improve } \\
\text { accessibility to and within the area. }\end{array}$ \\
\hline
\end{tabular}

This approach to spatially managing the flow of tourists creates a consensus upon which to base the decisions that need to be taken. As such, it can be employed directly in the planning process as well as in the formation of a tourism policy within the municipality. This makes it easier to achieve a desirable utilisation of the landscape as a leisure resource. Moreover, the basis for the community and the tourism sector will thereby be strengthened, which will in turn encourage sustainable development within each municipality. This will make it possible to host different types of visitors in the future without in so doing draining the resources that tourism relies upon more than is necessary.

\section{Discussion}

\subsection{Planning Sustainable Leisure Landscapes in Icelandic Rural Communities}

Leisure is currently exerting an increasing impact on natural environments worldwide. Tourism is viewed by many Arctic communities as a major catalyst for sustaining their viability. It is therefore important to achieve an acceptable balance between the various impacts which result from tourism development. In response to increased tourism impact, increasing demands are being placed on the tourism industry to assume the burden of responsibility in this regard. According to Goodwin (2011) responsible tourism is a matter of using tourism rather than being used by it - as currently seems to be the case in Skaftárhreppur municipality. Goodwin $(2011$, p. 250) demonstrates that tourism is simply what we make it, given that "we can make a difference [-] producers and consumers alike". As such, responsible tourism is also a matter of using tourism to activate sustainable development. The results of the present study support this conclusion and stress that in order for nature-based tourism to be responsible, land use planning and management is of critical importance. Furthermore, in order to develop site-specific zoning measures with respect to the landscape, nature, and society, sustainable land use planning for tourism requires a deep understanding of the landscape, its genesis and both regional and local characteristics.

Land use planning is inherently a complicated process entailing as it does a confrontation between different stakeholders over the use of land. This complexity only increases further in cases where a large part of the land 
resource comprises a common pool resource, as is the case in many municipalities in Iceland. Steering and managing the utilization of common pool resources such as areas of natural beauty and the landscape itself, which comprise tourism sector commodities, presents however a formidable challenge. Hardin's (1968) classical theory regarding the tragedy of the commons elucidates the issue at hand in seeking to clarify the predominant short-term interests of the user when it comes to the utilization of a common pool resource. Each user perceives an advantage in increasing their private exploitation - since the economic benefit of this exploitation goes directly to them - while they only have to bear a fraction of the cost which arises from the overexploitation of a resource. This has manifested itself e.g. in the overfishing of certain fish stocks, as well as in overgrazing, and it may also be said to apply to the tourism sector. Thus, diminishing satisfaction among tourists goes hand-in-hand with the presence of growing numbers of tourists at a destination, which in turn leads to diminishing profit per tourist. In spite of this development, tourist operators appear to keep on sending tourists to such destinations. The reason for this might be that the party that sells the tourist/tour group in question the trip receives the proceeds of the sales. However, the loss, i.e., the reduced price of the trip resulting from reduced customer satisfaction is distributed between all tourist operators that make use of the destination. In other words, the supplier receives all of the profit from the additional tourists but only has to bear a small fraction of the loss that is distributed amongst all parties who sell trips to the destination. This will lead to overexploitation of popular tourist destinations by the tourism sector if no intervening measures are taken. In order to avoid such overexploitation a clear and well-executed land use plan for tourism, with sustainable development and tourism carrying capacity as its cornerstones, is a key factor in ensuring that nature destinations continue to be a resource for Icelandic rural communities and the tourism sector. It is necessary to determine in precisely what areas to control and steer access to destinations, including where to channel mass tourism, along what procedures will be implemented to achieve such control. This conclusion is supported by Tverijonaite, Ólafsdóttir \& Thorsteinsson (2018) and Ólafsdóttir \& Haraldsson (2018), who conclude that improved access increases the demand for the additional infrastructure needed to cope with the environmental pressure from tourism.

\subsection{Holistic Approach and Aesthetic Value in Tourism Planning}

The paramount importance of preserving the original attraction at tourist destinations has long been recognised, not the least when it comes to natural attractions, given that such attractions are usually not renewable (e.g., Butler, 1980). The tourist attractions found in Skaftárhreppur municipality are largely based on natural phenomena characterized by a wild appearance, and sensitive landscapes with a low tolerance limit. According to surveys conducted among visitors to these attractions (i.e., Sæbórsdóttir et al., 2016; Sæpórsdóttir, 2012; Sæpórsdóttir \& Ólafsson, 2012) this wild or natural appearance is the main attraction of the area for tourists. As such, it is important to preserve these natural attractions given that they comprise the community's primary resource. Given the sensitivity of the area's natural phenomena the results of this study emphasize the importance of careful land use planning in order to manage the flow of tourists to the area and thereby increase the durability of the resource which stimulates sustainability. This is principally achieved by focusing on careful design with the aim of preserving the aesthetic value of the area for future tourism. Contrary to many public tourism destination management strategies (e.g., ITB, 2011) which stress the need to disperse the flow of tourists in order to relieve tourism pressure by establishing a widespread network comprising a large number of smaller sites, the results of the present study demonstrate the importance of tourism management in terms of canalizing the flow of tourists, with the aim of directing the mass tourism to carefully selected focal points. This will serve to reduce the environmental and social pressure from tourism, the communities' cost of maintaining the infrastructure, which in turn will ensure tourist satisfaction and protect the most sensitive areas from overexploitation by tourism.

\section{Conclusions}

Achieving long term sustainable tourism will undoubtedly increase the quality of life of Icelandic rural communities and the experience of its visitors. Such a future goal will nonetheless only be achieved by addressing the need for long-term and multi-scale zoning plans for tourism development. The recent growth of tourism in Iceland emphasizes the urgent need for a zoning plan in the short-term. However, given the aesthetic and ecological sensitivity of the Icelandic landscapes, it is additionally of critical importance to implement a long-term zoning plan. This is necessary on the one hand in order to preserve the natural landscape and wilderness, and on the other hand in order to avoid degrading the landscape through the unfettered development of infrastructure. Accordingly, a zoning plan based on the results of cooperation between all stakeholders' will contribute to a sustainable 'caretaking' of Icelandic landscapes by its inhabitants, providing them with a long-term vision of how to use their land efficiently in terms of the inherent value of the natural and cultural landscape. Only in this way can tourism increase the long-term welfare of the local population. 


\section{Acknowledgements}

We would like to acknowledge the mayor of Skaftárhreppur municipality Sandra Brá Jóhannsdóttir, the municipality’s planning representatives Vigfús Pór Hróbjartsson and Kristbjörg Hilmarsdóttir, the chair of the environmental and nature conservation board Jóna Björk Jónsdóttir, the director of Visit Klaustur Porbjörg Ása Jónsdóttir, park manager of the Vatnajökull National Park west territory Orri Páll Jóhannsson, and the director of the Katla Geopark Brynja Davíðsdóttir for their participation and fruitful cooperation during our focus group meetings. We would further like to thank Dr. Hugh Atkinson for English correction and our anonymous reviewers for valuable comments and suggestions which have led to significant improvement of this paper.

\section{References}

de la Barre, S., Maher, P., Dawson, J., Hillmer-Pegram, K., Huijbens, E., Lamers, M., ... Stewart, E. (2016). Tourism and Arctic Observation Systems: Exploring the relationships. Polar Research, 35(1), 24980. https://doi.org/10.3402/polar.v35.24980

Fay, G., \& Karlsdóttir, A. (2011). Social indicators for Arctic tourism: Observing trends and assessing data. Polar Geography, 34(1-2), 63-86. https://doi.org/10.1080/1088937X.2011.585779

Gill, A. (1998). Local and resort development. In R. Butler, M. C. Hall, \& J. Jenkins (Eds.), Tourism and Recreation in Rural Areas (chapter 6, pp. 97-111). John Wiley \& Sons.

Goodwin, H. (2011). Taking Responsibility for Tourism. Goodfellow Publishers.

Grenier, A. A., \& Müller, D. K. (Eds.). (2011). Polar tourism: A tool for regional development. Montreal: Presses del'Université du Québec.

Guðjónsson, G., \& Gíslason, E. (1998). Vegetation Map of Iceland, 1:500 000 Icelandic Institute of Natural History.

Hall, C. M., \& Saarinen, J. (2010). Tourism and change in Polar Regions: Climate, environment and experience. Oxton: Routledge. https://doi.org/10.4324/9780203851807

Hardin, G. (1968). The Tragedy of the Commons. Science, New Series, 162(3859) (Dec. 13, 1968), $1243-1248$.

Hendee, J. C., Catton, W. R., Jr, Marlow, L. D., \& Brockman, C. F. (1968). Wilderness users in the Pacific Northwest: Their characteristics, values, and management preferences (Research paper PNW). Portland: Pacific Northwest Forest and Range Experiment Station.

Huijbens, E. H. (2015). Cruise tourism in Iceland and the North Atlantic: Gateways to the Arctic and the challenges to port readiness programs. Tourism in Marine Environments, 10(3-4), $241-254$. https://doi.org/10.3727/154427315X14181438892928

Huijbens, E. H., \& Alessio, D. (2015). Arctic 'concessions' and icebreaker diplomacy? Chinese tourism development in Iceland. Current Issues in Tourism, 18(5), 433-449. https://doi.org/10.1080/13683500.2013.837867

Icelandic act on Vatnajökull National Park [Lög um Vatnajökulspjóðgarð] no. 60/2007.

ITB (Icelandic Tourist Board). (2011). Ferðamálaáæltun 2011-2020 [Tourism strategy 2011-2020]. Retrieved from

https:/www.ferdamalastofa.is/static/files/ferdamalastofa/Frettamyndir/2015/mars/ferdamalaaaetlun_2011_2 020_uppsett.pdf

ITB (Icelandic Tourist Board). (2017). Visitors to Iceland through Keflavik Airport, 2003-2017. Retrieved from http://www.ferdamalastofa.is/en/recearch-and-statistics/numbers-of-foreign-visitors

Jóhannesson, H. (2014). Geological map of Iceland, Bedrock Geology, 1:600 000. Icelandic Institute of Natural History.

Keskitalo, E. C. H. (2017). Images of the northern and 'arctic' in Tourism and regional literature. In A. Viken \& D. K. Müller (Eds.), Tourism and indigeneity in the Arctic (pp. 33-49). Bristol: Channel View Publications.

Lemelin, R. H., Maher, P., \& Liggett, D. (Eds.). (2013). From talk to action. How tourism is changing Polar Regions. Thunder Bay: Lakehead University Centre for Northern Studies.

McDonald, C. D. (2012). Understanding participatory action research: a qualitative research methodology option. Canadian Journal of Action Research, 13(2), 34-50. 
Müller, D. K. (2015). Issues in Arctic Tourism. In B. Evengård, L. J. Nymand, \& Ø. Paasche (Eds.), The New Arctic (pp. 147-158). https://doi.org/10.1007/978-3-319-17602-4_11

Müller, D. K., \& Brouder, P. (2014). Dynamic development or destined to decline? The case of arctic tourism businesses and local labour markets in Jokkmokk, Sweden. In A. Viken \& B. Granås (Eds.), Tourism Destination Development: Turns and Tactics (pp. 227-244). Farnham, UK: Ashgate.

Newsome, D., Moore, S. A., \& Dowling, R. (2013). Natural Area Tourism, ecology, impacts and management (2nd ed.). Channel View Publications.

NLSI (National Land Survey of Iceland). (2018). IS50v geodatabase, municipalities [IS50V_MORK_17062018_ISN2004] (data updated $17^{\text {th }}$ June 2018).

Noordhuizen, J., Nijkrake, W., Ólafsdóttir, R., \& Sæpórsdóttir, A. D. (2016). Destination: Iceland. Sustainable Leisure Landscapes in Skaftárhreppur. A holistic approach. Nohnik Architecture and Landscapes \& University of Iceland. Retrieved from https://issuu.com/nohnik/docs/nohnik_-_destination_iceland_lq

Ólafsdóttir, R., \& Dowling, R. (2014). Geotourism and Geoparks-a tool for geoconservation and rural development in vulnerable arctic environments. A case study from Iceland. Geoheritage, 6, 71-87. https://doi.org/10.1007/s12371-013-0095-3

Ólafsdóttir, R., \& Haraldsson, H. (2018). Tourism spatial dynamics and causal relations: A need for holistic understanding. In D. K. Müller (Ed.), A Research Agenda for Tourism Geographies. Edward Elgar Publishing (In press).

Ólafsdóttir, R., \& Júlíusson Á. D. (2000). Farmers' perception on land cover changes in NE Iceland. Land degradation and development, 439-458. https://doi.org/10.1002/1099-145X(200009/10)11:5<439::AID-LDR406>3.0.CO;2-K

Ólafsdóttir, R., \& Runnström, M. C. (2009). A GIS Approach to Evaluating Ecological Sensitivity for Tourism Development in Fragile Environments. A Case Study from SE Iceland. Scandinavian Journal of Hospitality and Tourism, 9(1), 22-38. https://doi.org/10.1080/15022250902761504

Ólafsdóttir, R., Sæbórsdóttir, A. D., \& Runnström, M. (2016). Purism Scale Approach for Wilderness Mapping in Iceland. In S. Carver \& S. Fritz (Eds.), Mapping wilderness: Concepts, Techniques and Applications (Chapter 11, pp. 157-176). Springer. https://doi.org/10.1007/978-94-017-7399-7_11

Saarinen, J., Rogerson, C. M., \& Hall, C. M. (2017). Geographies of tourism development and planning. Tourism Geographies, 19(3), 307-317. https://doi.org/10.1080/14616688.2017.1307442

Sæpórsdóttir, A. D. (2010) Planning nature tourism in Iceland based on tourist attitudes. Tourism Geographies, 12(1), 25-52. https://doi.org/10.1080/14616680903493639

Sæpórsdóttir, A. D. (2012). Ferðamennska á miðhálendi Íslands: Staða og spá um framtiððarhorfur. [Tourism in the Central Icelandic Highlands; Current position and forecast of future prospects]. Reykjavík: University of Iceland.

Sæpórsdóttir, A. D., \& Ólafsson, R. (2012). Áhrif Hólmsárvirkjunar á ferðamennsku og útivist [The effect of the proposed power plant Hómsárvirkjun on tourism and recreation] LV-2012-020. Reykjavík: Landsvirkjun and Orkusalan.

Sæpórsdóttir, A. D., \& Stefánsson, P. (2017). Ferðapjónusta og virkjanir til bjargar byggðum? [Can tourism and power plants aid rural communities?]. Tímarit um viðskipti og efnahagsmál, 14(1). https://doi.org/10.24122/tve.a.2017.14.1.5

Sæpórsdóttir, A. D., Guðmundsdóttir, A. M, Stefánsdóttir, B., \& Stefánsson, P. (2016). Viðhorf ferðamanna og ferðabjónustuaðila til Búlandsvirkjunar $i$ 3. áfanga rammaácetlunar. [Perception of tourists and tourist operators towards Búland power plant in the $3^{\text {rd }}$ Phase of the Master Plan for Nature Protection and Energy Utilization]. Reykjavík: University of Iceland.

Sæpórsdóttir, A. D., Ólafsdóttir, R., \& Ólafsson, R. (2009). Hálendi Íslands, auðlind útivistar og ferðamennsku [The Icelandic highlands, a resource for recreation and tourism]. Náttúrufrceðingurinn, 78(1-2), 33-46.

Senes, G., \& Toccolini, A. (1998). Sustainable land use planning in protected rural areas in Italy. Landscape and Urban Planning, 41, 107-117. https://doi.org/10.1016/S0169-2046(97)00064-9 
Stankey, G. H. (1973). Visitor perception of wilderness recreation carrying capacity (Vol. USDA Forest Service Research Paper INT - 142.) Ogden: Intermountain Forest \& Range Experiment Station, Forest Service, U.S. Dept. of Agriculture.

Statistics Iceland. (2017). Sveitarfélög og Byggðakjarnar [Municipalities and rural communities]. Retrieved from https://www.hagstofa.is/talnaefni/ibuar/mannfjoldi/sveitarfelog-og-byggdakjarnar/

Stewart, D. W., \& Shamdasani, P. N. (1990). Focus Groups, Theory and Practice. Applied Social Research Methods series, vol. 20. Thousand Oaks, California: Sage Publications.

Thordarson, Th., Larsen, G., Steinpórsson, S., \& Self, S. (2003). The 1783-1785 A.D. Laki-Grímsvötn eruptions II: Appraisal based on contemporary accounts. Jökull, 53, 11-48.

Pórhallsdóttir, G., \& Ólafsson, R. (2018). Fjöldi gesta i Vatnajökulspjóðgarði frá upphafi talninga út árið 2017 [Number of visitors to Vatnajökull National Park from the beginning of record-keeping until 2017]. Reykjavík: Vatnajökull National Park.

Tverijonaite, E., Ólafsdóttir, R., \& Thorsteinsson, Th. (2018). Accessibility of protected areas and visitor behaviour: A case study from Iceland. Journal of Outdoor Recreation and Tourism, 24, 1-10. https://doi.org/10.1016/j.jort.2018.09.001

UNESCO Global Geoparks. (2017). List of UNESCO Global Geoparks. Retrieved from http://www.unesco.org/new/en/natural-sciences/environment/earth-sciences/unesco-global-geoparks/list-ofunesco-global-geoparks/

Visit South Iceland \& ITB (Icelandic Tourist Board). (2018). Áfangastaðaáætlun DMP á Suðurlandi [Destination $\begin{array}{llllll}\text { Management Plan for } & \text { Southern } & \text { Iceland]. }\end{array}$ https://www.south.is/static/files/DMP/afangastadaaaetlun-dmp-sudurland-12.11.2018.pdf

VNP (Vatnajökull National Park). (2017). About Vatnajökull National Park. Retrieved from http://www.vatnajokulsthjodgardur.is/english/education/

Williams, P., \& Gill, A. (1994). Tourism Carrying Capacity Management Issues. In W. Theobald (Ed.), Global Tourism: The Next Decade (chapter 12, pp. 174-187). Boston: Butterworth Heinemann.

Zelenskaya, E. (2018). Geopolitics and tourism in the Arctic: the case of the national park 'Russian Arctic'. Journal of Policy Research in Tourism, Leisure and Events, 10(1), 33-47. https://doi.org/10.1080/19407963.2017.1324861

\section{Copyrights}

Copyright for this article is retained by the author, with first publication rights granted to the journal.

This is an open-access article distributed under the terms and conditions of the Creative Commons Attribution license (http://creativecommons.org/licenses/by/4.0/). 